\title{
Microbial Environmental Risks Associated Sewage Sludge Disposal
}

\author{
Roman Nega* \\ Faculty of Natural and Computational Sciences, Department of Biology, University of \\ Gondar, Ethiopia
}

*Corresponding author: Roman Nega, Faculty of Natural and Computational Sciences, Department of Biology, University of Gondar, Addis Ababa, Ethiopia, Tel: 0918169601;

\section{Mini Review}

Volume 3 Issue 2

Received Date: September 06, 2018

Published Date: October 09, 2018

DOI: $10.23880 /$ oajmb-16000131

Email: romannega32@gmail.com

\section{Abstract}

Sewage sludge disposal is a worldwide problem and a wide variety of disposal routes have been adopted as directed by local condition. Disposal of sludge to land can be beneficial because it contains plant nutrient (N and P) and organic matter. Sludge and sewage are a public health threat, which has been linked to respiratory problems and death. Sludge disposal is a major operational cost in the treatment of waste water and in the water industry tends to dispose of sludge at minimum cost consistent with ac ceptable environmental impact and with flexibility and security. All sludge in world contains heavy metals like arsenic, cadmium, chromium, copper, lead mercury, molybdenum, nickel, selenium, and zinc. Sewage sludge, by its very nature contains a wide variety of pathogens including bacteria, viruses, fungi and eggs of parasites. Pathogens may also enter the sewerage system from farm drainage, domestic animals, and the rodent population of the sewer sand surface water. Directly or indirectly in 1 year 300,000 tons of sewage sludge (dry weight bases) generated and disposed currently, about 17\% of the MSW (municipal solid wastes) is recycled; the other $83 \%$ is disposed of in landfills or incinerated. To avoid environmental problems it is necessary to recycle the sludge before disposal.

Keywords: Sewage Sludge; Waste Water Treatment; Environmental Protection Agency; Molybdenum

\section{Introduction}

\section{What is Sludge?}

Sludge is the solid, semi solid or liquid residue generated during treatment of domestic sewage [1]. The term bio solids were introduced by the waste water treatment industry in the early 1990's and is now also used by EPA (Environmental protection agency). Sewage sludge originates form the process of treatment of waste water. Due to physical-chemical processes involve in the treatment, the sludge trends to concentrate heavy metals 


\section{Open Access Journal of Microbiology \& Biotechnology}

and poorly biodegradable trace organic compounds as well as potentially pathogenic organisms (viruses, bacteria's, parasites, and protozoan). However, sludge is a rich in nutrients such as $\mathrm{N}$ and $\mathrm{P}$ and contain valuable organic matter used for fertilizer $[1,2]$.

Sewage sludge disposal is a worldwide problem and a wide variety of disposal routes have been adopted as directed by local condition [3]. The term bio solids recently have been introduced by the waste water treatment industry. The term is intended to distinguish high-quality treated sludge and from sludge that contains large quantities of environmental pollutants and it represents the insoluble residue produced during waste water treatment and sub sequent sludge stabilization procedures. Such as aerobic and an aerobic digestion [2].

\section{Benefit of Sludge}

Disposal of sludge to land can be beneficial because it contains plant nutrient ( $\mathrm{N}$ and $\mathrm{P}$ ) and organic matter. Sludge contains organic matter and nutrients that have the potential to enhance forest productivity and agricultural product. Bio solids provide direct economic benefits to forms, because the nutrients they contain inorganic fertilizers [4].

\section{Problem of Sludge}

Sludge contains measurable quantities of pollutants, such as heavy metals, toxic chemicals and dioxins. Sludge also contains pathogens like bacteria, viruses and parasites. And sludge smells sludge odor is more than just a nuisance: it is a public health threat, which has been linked to respiratory problems and death. The land application of sludge distributes pollutants from large towns and cities to rural areas, far from where they were originally produced. State and federal agencies of various countries regulate sludge spreading, but regulation of this waste is difficult and problematic [5].

\section{Composition of Sludge}

Sludge is composed of both toxic and non-toxic organic wastes and trace elements. Sludge is also contains pathogenic microbes like bacteria, viruses and protozoon's along with other parasitic helmets which can give rise to potential hazards to the health of humans, animals and plants. Apart from those components of concern sludge also contains useful concentration of nitrogen, phosphorus and organic matter [6]. Sludge microbes which can give rise to potential hazard to the crops, soil (farm lands) and ground water [7].

\section{Sources of Sewage Sludge}

Sources of sludge includes industrial hazards, small business (like dentist offices, photo developers, dry cleaners etc.), hospital hazards, house hold hazards (like bathing, cleaning, shampoo (hair coloring) [1].

\section{Industrial hazards}

As discussed earlier, many chemicals used by industry have not been properly tested and are not regulated or reported. Additionally, even at the safest facilities, accidents happen and toxic chemicals can be released into the waste stream. World requires wastewater treatment plants to work with large industries on reducing and monitoring their waste discharge. This "pretreatment process" is required of companies that discharge a large amount of waste into the sewer system or use a large amount of chemicals that could affect the operation of the sewer system. Unfortunately, once companies release heavy metals, or other toxins, into the sewer system, there is no process to remove these chemicals from the sludge. In addition, every industry in the country can discharge 33 pounds of hazardous waste every month into wastewater treatment plants, without penalty or reporting [1].

\section{Small business hazards}

Many small businesses are not regulated for their toxic releases. Nor are they included in the pretreatment processes. While auto garages, dentist offices, photo developers, dry cleaners, and other small businesses may not individually release a large amount of toxic chemicals, taken as a whole their contribution to chemicals in sludge could be dangerous [1].

\section{Hospital hazards}

All hospitals are required to dispose of toxic chemicals and biohazards in a state approved manner. Nevertheless, accidents do happen: from a broken mercury thermometer to additional human pathogens being washed down the drain, hospitals can contaminate sludge [1].

\section{Household hazards}

From pesticides (including flea shampoos), to heavy duty cleaning agents and hair coloring products, toxic chemical containing products abound. Any of these chemicals dumped down the drain could end up being spread on a farm field or in a forest [1].

\section{Ways of Pathogen Transfer}

Pathogens can be transported through water, stock pods and surface water through food .contamination from 
eating food grown in sludge spread land. Pathogens can be transported to humans who walk through sludge speed fields. Wild animals, from animals, birds, rodents and pets may become infected by sludge pathogens. There is no requirement to post signs that sludge has been spread or stored [8].

Bio aerosol risk: A recent study from the University of Arizona shows that the risk of windborne pathogens is significant within a $10 \mathrm{~km}$ radius of a sludge spread field. In Canada, the relatively cooler and wetter climate may make this risk even higher [8].

Risk to water: Sewage sludge contains a high concentration of wastes; indeed, a 100-acre spread of sewage sludge represents the annual fecal output of approximately 1400 people plus the industrial waste component. To compare sludge with manure, a field of similar size would support 100 cattle [8]. Some provinces have 'guidelines' or other criteria that are intended to address the environmental and health issues related to the land application of sewage sludge. However, these 'guidelines' are not always enforceable, and most are not legally binding. Ontario has one of the most detailed documents on the land application of sewage sludge and other organic waste. However, the Guidelines for the Use of Biosolids and Other Wastes on Agricultural $L$ and are only a 'guidelines'. They are not statutes or regulations. In Ontario, even after the Walkerton tragedy, reductions were allowed in the the separation distances between sludge spreading sites and drinking wells, lakes, rivers and surface waters. Ottawa and Toronto are currently allowed to spread sludge as close as $15 \mathrm{~m}$ to a drilled drinking water well and as close as $15 \mathrm{~m}$ to surface water despite provincial law that stipulates greater, more protective distances [8].

Animal transfer: Farm animals and pets such as cats and dogs can be expected to continue to travel through fields, even after the fields have been spread with sludge, and return to their owner's homes, spreading sewage sludge to the family home. Birds may also visit sludge spread fields, and spread viruses, bacteria and parasites in their subsequent droppings [8].

\section{Review of Literature}

\section{Hazards Associated with Sludge Disposal}

\section{Land pollution}

Sludge disposal is a major operational cost in the treatment of waste water and in the water industry tends to dispose of sludge at minimum cost consistent with acceptable environmental impact and with flexibility and security. Sludge is rich in organic matter ( $\mathrm{N}$ and $\mathrm{P}$ ) and trace elements. Depending on the environmental factors and the species of bacteria, survive times can range from weeks to months. Although some bacteria are grow under certain circumstances such as rain fall, very few species of human pathogenic bacteria can do so. Helminthes are the most persistent pathogens with as carries eggs surviving for years in soil $[7,9]$.

\section{Atmospheric Pollution}

Particles released during aeration unit of the activated sludge process and from the distributer nozzles on percolating filters. The areoles from sewage treatment plant can contain any of the pathogenic bacteria, viruses or endotoxins associated with sewage and can infect animals or humans by inhalation [3].

\section{Water pollution}

Diseases that are commonly associated with fecal contamination of water in temperate regions include Bacteria Salmonella (typhoid, paratyphoid, and food poisoning), Shigella (bacterial dysentery), Mycobacterium (tuberculosis) and Leptospira ictrohacmorrhagia (leptospira jaundice). Viruses are excreted in large number infects. The most important one in terms of human infection is hepatitis A and there is direct link between fatal contamination of water supplies and bathing water and infection [10]. The level of infection will depend on a number of factors such as the density of the pathogen in water, the toxigenicity of the pathogen, the degree of contact between immune of individuals once excreted, pathogens are in a hostile environment and their numbers rapidly decline [11]. However, the chance of infection decreases after treatment. Microbes contaminate ground water, tanks and rivers [12].

\section{Toxic in Sludge}

\section{Heavy metals}

All sludge in world contains heavy metals like arsenic, cadmium, chromium, copper, lead mercury, molybdenum, nickel, selenium, and zinc [13]. Even small amounts of heavy metals in sludge, are dangerous, high level of arsenic in food and water can be fatal. Cadmium has also been linked to kidney problems miscarriage and stillbirths. Copper, nickel and zinc known to Cause growth problems in crops. Children exposed to lead can develop behavioral and learning problems. Mercury exposure at key moments in fetal development can cause learning disabilities and neurological disorders. Molybdenum bio accumulates in grass eating live stock; ingested in excess, 


\section{Open Access Journal of Microbiology \& Biotechnology}

it can cause anemia, diarrhea and growth problems $[6,14]$.

\section{Microbial hazards}

Sewage sludge, by its very nature contains a wide variety of pathogens including bacteria, viruses, fungi and eggs of parasites. Pathogens may also enter the sewerage system from farm drainage, domestic animals, and the rodent population of the sewer sand surface water [15].

E -coli in sludge contaminate the drinking water and occur in domestic waste water. It is common biocides and cause diarrhea for humans and mortality in young children by drinking contaminate water. Salmonella is the most extensively studied bacteria with regard to survival in sewage sludge. Interestingly, these bacteria survive for more than 1 year in the environment. Salmonella species in the majority of sewage sludge samples from treatment plants including raw and digested sludge. Specially, they were detected in 55\% of the digested sludge samples. Clostridium species and bacillus species are sporeforming bacteria that grow as vegetative cells clostridium tyrobutyricum causes big economic loses to the diary industry by transfer to cows and eventually to milk. As per gillus fumigatus found in compositing repetition and the composting mixture consists a raw sewage sludge mixture with wood chips (major source of fungus) as bulking agent. Hepatitis A Virus is water born disease $[5,13]$.

Directly or indirectly in 1 year 300,000 tones of sewage sludge (dry weight bases) generated and disposed currently, about $17 \%$ of the MSW (municipal solid wastes) is recycled; the other $83 \%$ is disposed of in landfills or incinerated [4].

\section{Conclusion}

The aim of this study was to address the microbial environmental associated with sewage sludge disposal, and based on the literature review result the following conclusion were drawn

1. Sludge contains measurable quantities of pollutants such as toxic chemicals, heavy metals and microbes.

2. Sludge is a major public health and environmental disaster throughout the world.

3. Heavy metal accumulation exist in plants that their ultimate destination were human being and living creatures as well as the environmental risk exposed to both soil and crops.

4. Microbes in sludge can be transfer by means of bio aerosols animals, insects, birds and humans etc.

\section{Summary}

Sludge is the solid, semi solid or liquid residue generated during treatment of domestic sewage. The term bio solids were introduced by the waste water treatment industry in the early 1990's and is now also used by EPA (Environmental protection agency). Sewage sludge originates form the process of treatment of waste water. Due to physical-chemical processes involve in the treatment, the sludge trends to concentrate heavy metals and poorly biodegradable trace organic compounds as well as potentially pathogenic organisms (viruses, bacteria's, parasites, and protozoan). Disposal of sludge to land can be beneficial because it contains plant nutrient (N and P) and organic matter. Sludge contains organic matter and nutrients that have the potential to enhance forest productivity and agricultural product. Bio solids provide direct economic benefits to forms, because the nutrients they contain inorganic fertilizers.

Sludge contains measurable quantities of pollutants, such as heavy metals, toxic chemicals and dioxins. Sludge also contains pathogens like bacteria, viruses and parasites. Sludge is composed of both toxic and non-toxic organic wastes and trace elements. Sludge is also contains pathogenic microbes like bacteria, viruses and protozoon's along with other parasitic helmets which can give rise to potential hazards to the health of humans, animals and plants. Sources of sludge includes industrial hazards, small business (like dentist offices, photo developers, dry cleaners etc.), hospital hazards, house hold hazards like bathing, cleaning, shampoo (hair coloring). The areoles from sewage treatment plant can contain any of the pathogenic bacteria, viruses or endotoxins associated with sewage and can infect animals or humans by inhalation. All sludge in world contains heavy metals like arsenic, cadmium, chromium, copper, lead mercury, molybdenum, nickel, selenium, and zinc.

Sewage sludge, by its very nature contains a wide variety of pathogens including bacteria, viruses, fungi and eggs of parasites. Pathogens may also enter the sewerage system from farm drainage, domestic animals, the rodent population of the sewer sand surface water. Directly or indirectly in 1 year 300,000 tones of sewage sludge (dry weight bases) generated and disposed currently, about $17 \%$ of the MSW (municipal solid wastes) is recycled; the other $83 \%$ is disposed of in landfills or incinerated.

\section{Recommendation}

Prohibit sludge that contains industrial discharges and domestic discharges from being land applied. 


\section{Open Access Journal of Microbiology \& Biotechnology}

Sludge with bacteria, viruses and parasites should not be land applied

> To avoid environmental problems it is necessary to recycle the sludge before disposal.

$>$ Improper sewage sludge disposal should be practiced by the community.

\section{References}

1. Arvind K (2004) Environmental pollution. A text book of environmental science. New Delhi, India, pp: 133174.

2. Dart RK, Stretton RJ (1997) Microbial aspects of pollution control. Elsevier, Oxford.

3. Pandey GN (2003) Solid waste disposal. Environmental management, Delhi, India, pp: 182185.

4. Olenchock SA (1997) Airborne endotoxin. In: Manual of environmental microbiology, pp: 79-82.

5. Sharma PD (2002) Environmental pollution and public health. Environmental biology $2^{\text {nd }}$ (Ed.), New Delhi, India, pp: 182-185.

6. Wong JW, Li KL, Zhou LX, Selvan A (2007) Heavy metals derived from sludge. Journal of Environmental Quality 30: 878-883.

7. Atlas R, Bartha R (1987) Land application of Biosolids. Microbial ecology $2^{\text {nd }}(E d)$, The Benjamin/
Cummings publishing co., menlopark, CA, pp: 154193.

8. Raina M, Maier IL, Charles P, Gebra P (2000) The risk of pathogens to the environment. Environmental microbiology. Elsevier publishing co, USA, pp: 79-123.

9. Evanylo GK (2003) Land application of Biosolids for agricultural purposes in Virginia. Virginia Cooperative Extension Publication, pp: 452-300.

10. US Environmental protection agency. A plan English guide to the EPA part 503 Biosolids Rule.

11. Qin Lu, Zhenli LH, Peter JS (2012) Land Application of Biosolids in the USA: A Review. Hindawi Publishing Corporation Applied and Environmental Soil Science 1-11.

12. http:// www. epa. gov/owm/mtb/biosolids/503pe/pdf-aug 21. 2001.

13. Fennell $\mathrm{H}$ (1978) The reason for disinfection, water officers' Journal 11: 19-26.

14. Zhou LX, Wong JWC (2001) Effect of dissolved organic matters derived from sludge and composted sludge on soil CU sorption. J Environ Qual 30(3): 878883.

15. The spreading of Toxic sludge in Vermont. Public interest Research Group 802: 223-225. 